\title{
PELATIHAN DAN PENDAMPINGAN PEMBUATAN MEDIA PEMBELAJARAN SAINS INTERAKTIF DAN EASYQUIZZY BAGI GURU MGMP IPA KABUPATEN BENGKAYANG
}

\author{
Nawawi ${ }^{1^{*}}$, Handi Darmawan ${ }^{2}$ \\ ${ }^{1,2}$ Pendidikan Biologi, IKIP PGRI Pontianak, Indonesia \\ nawawi@ikippgriptk.ac.id
}

\begin{abstract}
ABSTRAK
Abstrak: Berdasarkan hasil wawancara dengan pengurus MGMP IPA Kabupaten Bengkayang, diperoleh informasi bahwa banyak guru IPA yang berkeinginan untuk dapat membuat media pembelajaran yang dapat digunakan untuk mengajar di kelas sesuai dengan karakteristik materi dan kondisi lingkungan serta sarana prasarana di sekolah. Program Pengabdian Kepada Masyarakat ini bertujuan untuk meningkatkan kompetensi guru-guru MGMP IPA Kabupaten Bengkayang dalam pembuatan media pembelajaran Sains Interaktif menggunakan sofware macromedia Flash sesuai dengan karakter materi IPA dan pembuatan soal interaktif menggunakan sofware Easy Quizzy. Metode yang digunakan adalah pelatihan dan pendampingan, yang dilaksanakan di SMPN 1 Teriak Kabupaten Bengkayang, Provinsi Kalimantan Barat pada tanggal 22 sampai dengan 24 Oktober 2018.
\end{abstract}

Kata Kunci: Pelatihan, Pendampingan, Media Pembelajaran, Sains, EasyQuizzy

Abstract: Based on the results of interviews with the management of the MGMP Natural Sciences Bengkayang Regency, information was obtained that many science teachers who wish to be able to make learning media that can be used to teach in a class by following the characteristics of the material and environmental conditions and also infrastructure in schools. This Community Service Program aims to improve the competency of Bengkayang Regency MGMP teachers in making Interactive Science learning media using Macromedia Flash software by following the character of the science material and making interactive questions using Easy Quizzy software. The method used is training and mentoring, which was carried out at SMPN 1 Teriak, Bengkayang Regency, West Kalimantan Province on October 22-24, 2018.

Keywords: Training, Assistance, Learning Media, Science, EasyQuizzy

\section{A. LATAR BELAKANG}

Dewasa ini, penting sekali profesionalisme guru ditingkatkan di bidang IT (Runtu I.; Tangkawarow, Indra V., 2013), (Nurdin, Sulastri, \& ., 2018). Salah satu kemampuan yang dimaksud adalah pemanfaatan media pembelajaran berbasis IT di dalam kelas (Wahyuningsih, Jamaluddin, \& Karnan, 2015). Selanjutnya, penggunaan media tentunya harus didukung oleh kemampuan guru dalam mengembangkannya, salah satu program computer yang bisa dikembangkan menjadi media interaktif adalah macromedia flash (Awwali, 2011). 
Hasil wawancara yang dilakukan dengan pengurus MGMP IPA di Kabupaten Bengkayang, diperoleh informasi bahwa banyak guru IPA yang berkeinginan untuk dapat membuat media pembelajaran berbasis IT. Guru IPA di MGMP IPA Kabupaten Bengkayang juga sangat kekurangan pelatihan baik yang diselenggarakan sekolah maupun dari pemerintah untuk meningkatkan keahlian guru-guru IPA di bidang media pembelajaran. Kurangnya pengetahuan guru IPA di MGMP IPA Kabupaten Bengkayang dalam pembuatan Media Pembelajaran Interaktif, serta keinginan guru yang kuat untuk memajukan pendidikan IPA melalui penggunaan media berbasis IT menjadi dasar untuk melaksanakan pelatihan atau workshop tentang media pembelajaran interaktif (Ikhwanudin \& Basith, 2018). Berdasarkan permasalahan di atas maka diperlukan upaya untuk meningkatkan ketrampilan guru dalam pembuatan media interaktif melalui kerjasama antara Program Studi Pendidikan Biologi dengan MGMP IPA Kabupaten Bengkayang dan PGRI Provinsi Kalimantan Barat, maka kemudian dilaksanakanlah kegiatan pelatihan dan pendampingan (Workshop) dalam pembuatan Media Pembelajaran Sains Interaktif dan pembuatan soal interaktif menggunakan software Easy Quizzy.

UU No. 23 Tahun 2003 tentang sistem pendidikan nasional, dimana guru profesional harus memiliki empat standar kompetensi, yaitu; kompetensi pedagogik, kompetensi kepribadian, kompetensi profesional, dan kompetensi social (Lestari \& Purwanti, 2018). Sedangkan menurut permendikbud no 22 tahun 2016 dijelaskan bahwa sumber belajar, dapat berupa buku, media cetak dan elektronik, alam sekitar atau sumber belajar lain yang relevan (Salmawati, Rahayu, \& Lestari, 2017). Media belajar juga menjadi bagian tidak terpisahkan dari RPP yang dibuat oleh guru (Suciati \& Astuti, 2016). Salah satu upaya yang dapat dilakukan oleh guru MGMP IPA Kabupaten Bengkayang untuk mengembangkan diri adalah dengan menguasai pembuatan media berbasis IT yang dapat diterapkan dalam pembelajaran di kelas.

Tujuan yang ingin dicapai dalam kegiatan ini adalah untuk meningkatkan kompetensi guru-guru IPA dalam pembuatan media pembelajaran sains interaktif menggunakan sofware Macromedia Flash sesuai dengan karakter materi dan sekolah di Kabupaten Bengkayang dan membuat soal interaktif menggunakan Easy Quizzy. Kegiatan Pengabdian yang akan dilakukan diharapkan memberikan manfaat bagi guru dalam pembuatan media pembelajaran yang lebih kreatif, inovatif dan berbasis IT.

\section{B. METODE PELAKSANAAN}

Rancangan kegiatan Pengabdian Kepada Masyarakat ini menggunakan metode pelatihan dan pendampingan, dengan beberapa tahapan. Adapun gambar metode pelaksanaannya adalah sebagai berikut: 


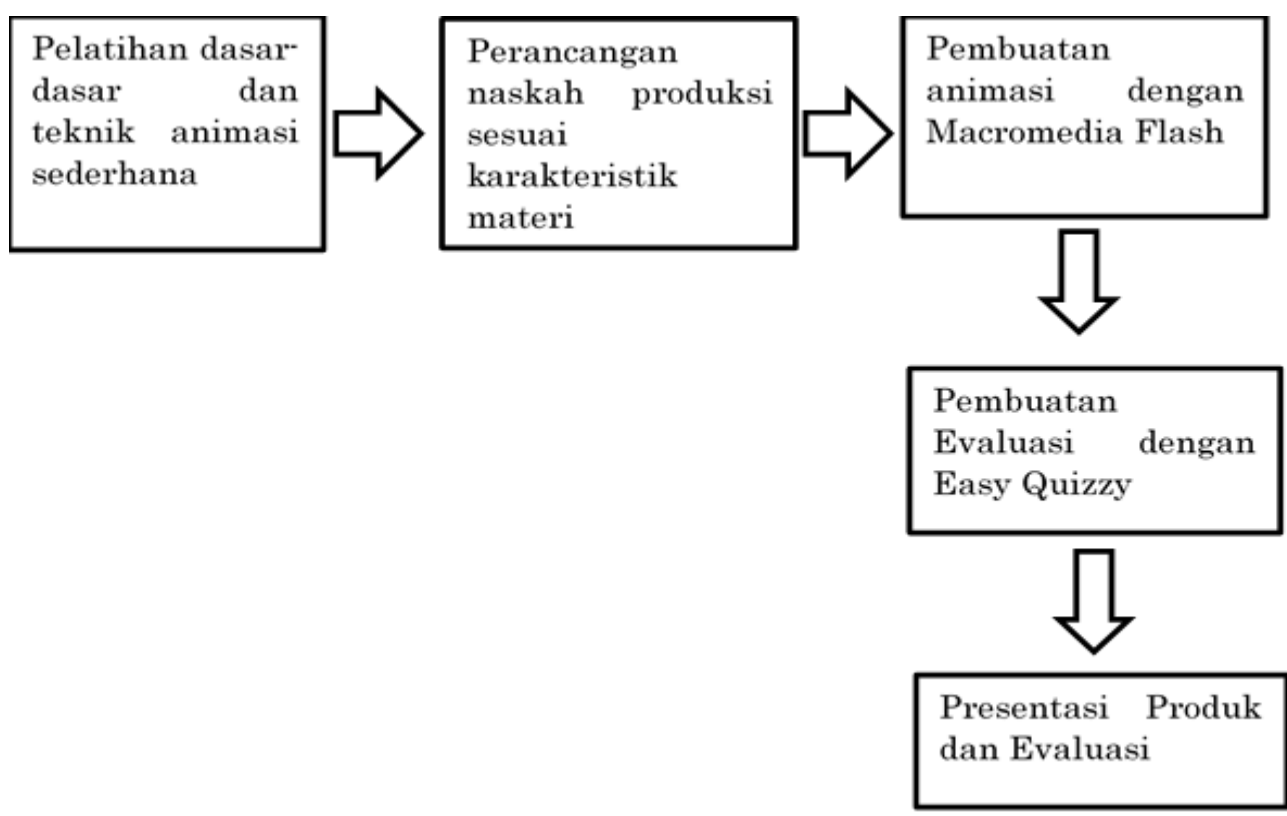

Gambar 1. Diagram Alur pelaksanaan Pengabdian Kepada Masyarakat

Kegiatan Pengabdian Kepada Masyarakat (PkM) Program Studi Pendidikan Biologi dilaksanakan pada pada tanggal 22 sampai dengan 24 Oktober 2018 di SMPN 1 Teriak Kabupaten Bengkayang. Peserta kegiatan adalah guru-guru yang berasal dari MGMP IPA Kabupaten Bengkayang.

Kegiatan yang akan dilaksanakan ini melibatkan 2 orang Dosen Prodi Pendidikan Biologi dan mahasiswa sebanyak 4 orang. Adapun tahapan pelatihan dan pendampingan pembuatan media pembelajaran sains interaktif dan Easy Quizzy adalah sebagai berikut:

\section{Tahap Persiapan Pelaksanaan PkM}

Sebelum pelaksanaan kegiatan PkM, program Studi Pendidikan Biologi melakukan rapat koordinasi dan komunikasi dengan pengurus MGMP IPA Kabupaten Bengkayang. Setelah terbentuk kepanitian, ketua panitia selanjutnya melakukan pembagian tugas sesuai dengan job description yang telah diputuskan, maka program studi meminta dosen yang ditunjuk yaitu; Nawawi, S.Pd, M.Pd dan Handi Darmawan, ST., M.Pd untuk mempersiapkan modul dan bahan materi pelatihan.

\section{Tahap Pelaksanaan PkM}

Kegiatan pelatihan dan pendampingan pembuatan media pembelajaran sains interaktif dan Easy Quizzy yang direncanakan telah berlangsung selama tiga hari dengan metode yang dilakukan yaitu metode pelatihan serta metode pendampingan. Guru-Guru IPA mendapatkan praktik langsung serta pendampingan oleh dosen-dosen, selain pelaksanaan praktik langsung pembuatan media pembelajaran sains interaktif menggunakan sofware macromedia flash, para guru juga di minta untuk membuat desain rencana produksi media pembelajaran sesuai dengan materi dan kompetensi masing-masing. Guru-guru IPA juga mendapatkan pelatihan dan pengampingan pembuatan soal interaktif menggunakan sofware EasyQuizzy. Pembuatan media 
pembelajaran dipandu oleh Nawawi, M.Pd sebagai praktisi utama, yang akan dibantu oleh Handi Darmawan, ST., M.Pd yang juga sebagai tim dosen pendukung dalam menjelaskan materi kepada peserta pelatihan dan pendampingan pembuatan media pembelajaran sains interaktif dan Easy Quizzy .

\section{Tahap Evaluasi PkM}

Proses evaluasi kegiatan PkM akan dilasanakan dengan meminta guru mempresentasikan media pembelajaran sains interaktif yang telah dibuatnya, sedangkan untuk pembuatan soal interaktif menggunakan Easy Quizzy dilakukan dengan meminta rekan guru lain mencoba menjawab soal yang dibuat oleh guru lain. Pemateri juga membagikan angket kepada para peserta. Angket yang diberikan kepada peserta dengan mengacu pada 5 indikator, yaitu: (1) keahlian dan kesiapan fasilitator dalam penyampian materi, (2) kegunaan materi yang disampaikan, (3) kesesuaian materi yang disampaikan dengan tema PkM, (4) kesesuaian pelaksanaan kegiatan dengan harapan peserta, (4) kesesuaian fasilitas yang diberikan pada saat pelaksanaan kegiatan.

\section{HASIL DAN PEMBAHASAN}

Pelaksanaan kegiatan pengabdian kepada masyarakat, berupa pelatihan dan pendampingan pembuatan media pembelajaran sains interaktif dan Easy Quizzy bagi guru MGMP IPA Kabupaten Bengkayang terdiri dari beberapa tahapan. Tahapan awal terdiri dari tahap persiapan, tahap perencanaan, tahap pelaksanaan, dan tahap evaluasi.

\section{Tahap Persiapan}

Pada tahap ini dilakukan komunikasi dan koordinasi dengan pengurus MGMP IPA Kabupaten Bengkayang, yang menjadi ketua panitia kegiatan. Proses komunikasi dilakukan untuk membahas maksud dan tujuan kegiatan serta menyampaikan jadwal pelaksanaan kegiatan. Pada tahap ini juga membahas tentang jumlah peserta yang akan diundang, dan kesiapan sarana pendukung di SMPN 1 Teriak sebagai tempat pelaksanaan kegiatan dan setiap peserta pelatihan diwajibkan untuk membawa laptop untuk selanjutnya akan di instal macromedia flash 8 portable dan software Easy Quizzy yang dapat digunakan untuk mengerjakan penugasan yang diberikan.

Pada tahap persiapan tim PkM juga menyiapkan materi pelatihan yang akan diberikan. Materi pelatihan berupa handout yang mencakup dasar-dasar pembuatan media pembelajaran sains interaktif menggunakan software macromedia flash dan handout pembuatan soal interaktif menggunakan software easy quizzy. Dikarenakan cakupan materi cukup luas, maka harus ditentukan materi-materi mana sajakah yang penting untuk disampaikan, agar peserta mudah untuk memahami langkah-langkah pembuatan, namun juga memahami konsep perencanaan dalam pembuatan media 
pembelajaran sains interaktif dan pembuatan soal evaluasi interaktif. Selain materi dalam handout, juga disiapkan contoh-contoh gambar, suara maupun video untuk dapat digunakan oleh peserta dalam pelatihan dan pendampingan.

\section{Tahap Perencanaan}

Dalam tahap perencanaan ini tim PkM dan pengurus MGMP IPA Kabupaten Bengkayang telah merencanakan susunan kegiatan pelatihan yang akan dilaksanakan dalam 3 hari. Agar penggunaan waktu dapat berjalan efisien dan materi yang telah disiapkan dapat terserap seluruhnya maka disusun rencana kegiatan sebagai berikut

a. Hari Pertama

1) Pembukaan Pelatihan oleh Dinas Pendidikan dan Ketua PGRI Provinsi Kalimantan Barat.

2) Pembuatan Naskah Produksi

3) Pelatihan tentang konsep dan pengenalan Tools dan Button Macromedia Flash

4) Pelatihan dan pendampingan pembuatan animasi sederhana menggunakan macromedia flash, adapun materi pada pertama adalah sebagai berikut:

a) Pembuatan berbagai object, (lingkaran, kotak, button, dll)

b) Pembuatan Animasi Sederhana (motion tween, motion shape, guide line, Animasi Text)

c) Pembuatan Opening Sederhana

d) Menambahkan suara kedalam animasi

e) Menambahkan Media Audio berupa musik latar dan narasi

f) Menambahkan acrtion script pada button

g) Membuat Animasi Sistem Pencernaan Pada Manusia (membuat Animasi Bolus bergerak dari mulut hingga ke anus); serta mengatur layout dan export hasil animasi

b. Hari Kedua

Melanjutkan pelatihan dan pendampingan dengan materi sebagai berikut:

1) Pengumpulan Naskah Produksi

2) Pembuatan Media Pembelajaran Sains Interaktif sesuai dengan Naskah yang dibuat

3) Pembuatan animasi opening media, interface tampilan, tombol, memasukkan teks dan gambar, membuat action script (bahasa pemrograman) untuk menjalankan tombol dan animasi

4) Instalasi Software Easy Quizzy ke dalam Laptop

5) Pelatihan pembuatan soal evaluasi interaktif menggunakan Easy Quizzy sesuai dengan materi dari peserta 
c. Hari Ketiga

Melanjutkan pelatihan dengan kegiatan sebagai berikut:

1) Melakukan presentasi media pembelajaran sains interaktif yang telah dibuat oleh peserta kegiatan

2) Melakukan uji coba soal evaluasi interaktif yang telah dibuat oleh peserta

3) Melakukan evaluasi kegiatan

4) Penutupan kegiatan

5) Pembagian sertifikat kepada peserta

\section{Tahap Pelaksanaan}

Tahap pelaksanaan dilakukan sesuai dengan rencana kegiatan yang telah disusun. Pelaksanaan kegiatan dilakukan pada tanggal 22 sampai dengan 24 Oktober 2018 di SMPN 1 Teriak Kabupaten Bengkayang. Pembukaan acara dimulai pada pukul 08.00 oleh Dinas Pendidikan Kabupaten Bengkayang dan Ketua PGRI Provinsi Kalimantan Barat, kemudian dilakukan pembagian materi berupa handout yang nantinya akan digunakan dalam pelatihan dan pendampingan pembuatan media pembelajaran sains interaktif dan handout Easy Quizzy.

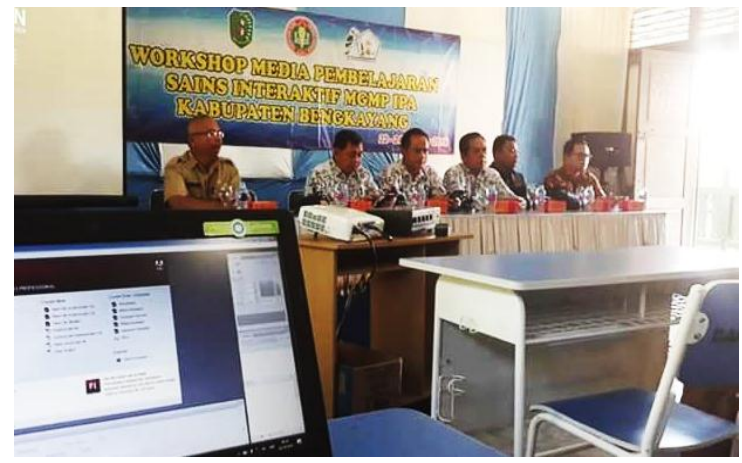

Gambar 1. Pembukaan Kegiatan Workshop Media Pembelajaran

Pemateri selanjutnya memberikan pelatihan dan pendampingan tentang pembuatan media pembelajaran sains interaktif menggunakan software macromedia flash dan pembuatan soal evaluasi interaktif menggunakan sofware Easy Quizzy. Proses pelatihan dimulai dengan penjelasan konsep pembuatan media pembelajaran berbasis macromedia flash, pembuatan naskah produksi media dan pengenalan lingkungan kerja aplikasi Macromedia flash.

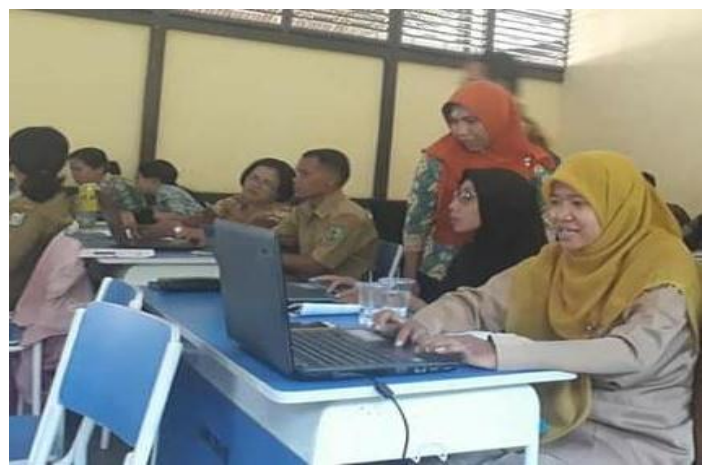

Gambar 2. Pemberian Materi Pembuatan Media Pembelajaran 
Setelah dilakukan penjelasan singkat tentang pembuatan naskah produksi media pembelajaran berbasis Macromedia flash, kegiatan selanjutnya adalah kegiatan pelatihan dan pendampingan sesuai dengan susunan materi yang telah direncanakan. Proses pelatihan berdasarkan susunan materi yang telah direncanakan bertujuan mengajarkan secara langsung tahap demi tahap proses penambahan berbagai macam media, baik itu teks, gambar, suara maupun video serta pembuatan animasi sederhana sesuai konsep IPA (Sains) baik Fisika maupun Biologi. Sedangkan untuk pembuatan soal evaluasi interaktif menggunakan sofware Easy Quizzy dilakukan pada hari kedua karena langkah dan metodenya lebih mudah dibandingkan mengajarkan pembuatan media menggunakan software macromedia flash.

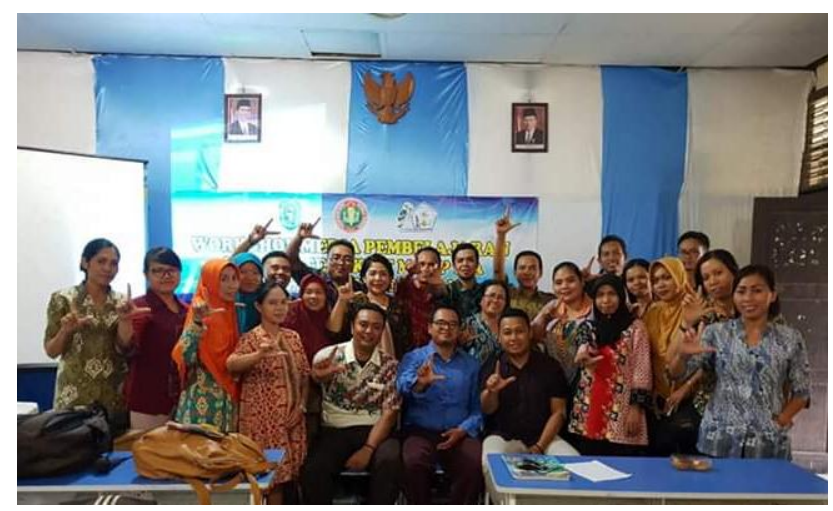

Gambar 3. Pemateri dan Peserta MGMP IPA Kabupaten Bengkayang

Setelah proses pelatihan dan pendampingan yang berjalan selama 3 hari, proses terakhir adalah evaluasi dengan menampilkan hasil dari pembuatan media pembelajaran sains interaktif menggunakan macromedia flash dan soal evaluasi yang dibuat menggunakan software Easy Quizzy yang telah dibuat oleh peserta sebagai tugas terstruktur, kemudian dilakukan evaluasi dan pemberian saran serta masukan pemateri.

\section{Tahap Evaluasi}

Berdasarkan hasil evaluasi diperoleh hasil bahwa guru mata pelajaran IPA Kabupaten Bengkayang telah mampu untuk membuat naskah produksi media pembelajaran sesuai dengan materi yang diajarkan, hal ini terlihat dari naskah yang dikumpulkan sudah mencakup keseluruhan materi yang diajarkan. Guru-guru MGMP IPA Kabupaten Bengkayang juga telah menguasai pembuatan soal interaktif menggunakan software easy quizzy.

Kesulitan yang dialami peserta terjadi dikarenakan; 1) peserta tidak semuanya memahami bahasa pemrograman atau action script sehingga kesulitan dalam menulis program untuk menjalankan animasi. 2) sofware macromedia flash 8 portable dan software Easy Quizzy yang diinstalkan kepada laptop peserta banya dianggap virus, sehingga sofware tidak dapat berjalan dengan baik, 3) animasi yang dibuat masih 
kaku, sehingga perlu latihan dan pengulangan pembuatan animasi sendiri agar animasi yang dibuat lebih halus, maka sangat diperlukan waktu lebih untuk memperdalam bahasa pemrograman dan animasi.

\section{SIMPULAN DAN SARAN}

Setelah dilaksanakannya kegiatan PKM selama tiga hari, beberapa hal yang dicapai dari pelatihan dan pendampingan adalah: (1) Guru MGMP IPA Kabupaten Bengkayang mampu memanfaatkan program Macromedia Flash untuk digunakan dalam pembuatan media pembelajaran Sains Interaktif sesuai materi; (2) Guru MGMP IPA Kabupaten Bengkayang mampu memanfaatkan program Easy Quizzy untuk digunakan dalam pembuatan soal evaluasi interaktif; (3) Guru MGMP IPA Kabupaten Bengkayang telah mampu membuat naskah produksi media pembelajaran Sains Interaktif..

\section{UCAPAN TERIMA KASIH}

Terima kasih diucapkan Kepada Program Studi Pendidikan Biologi IKIP PGRI Pontianak, MGMP IPA Kabupaten Bengkayang dan PGRI Provinsi Kalimantan Barat yang telah memfasilitasi dan mendukung kegiatan ini.

\section{DAFTAR RUJUKAN}

Awwali, M. R. (2011). Media Pembelajaran Desain Grafis Di SMA 1 Kudus Berbasis Multimedia Interaktif. Semarang, Sekolah Tinggi Elektronika Dan Komputer (STEKOM), 1-16.

Ikhwanudin, I., \& Basith, A. (2018). Pengembangan Media Pembelajaran Interaktif Fluida Statis dalam Perspektif Al-Qur'an Menggunakan Macromedia Flash. Indonesian Journal of Science and Mathematics Education, 1(3), 217-225. https://doi.org/10.24042/ijsme.v1i3.3596

Lestari, Y. A., \& Purwanti, M. (2018). Hubungan Kompetensi Pedagogik, Profesional, Sosial, Dan Kepribadian Pada Guru Sekolah Nonformal X. Jurnal Kependidikan, 2(1), 197-208.

Nurdin, F., Sulastri, T., \& . H. (2018). Pengaruh Penggunaan Media Pembelajaran Berbasis Macromedia Flash 8 Pada Model Pembelajaran Kooperatif Melalui Pendekatan Saintifik Terhadap Motivasi Dan Hasil Belajar (Study Pada Materi Pokok Laju Reaksi). Chemistry Education Review (CER), (1), 29. https://doi.org/10.26858/cer.v0i1.5607

Runtu I.; Tangkawarow, Indra V., P. V. J. . D. (2013). Pengaruh Media Pembelajaran Dengan Pemanfaatan Macromedia Flash Terhadap Hasil Belajar Siswa Pada Materi Statistika. Jsme Mipa Unima, (Vol 1, No 4 (2013): Matematika).

Salmawati, Rahayu, T., \& Lestari, W. (2017). Kontribusi Kompetensi Pedagogik , Kompetensi Profesional dan Motivasi Kerja terhadap Kinerja Guru Penjasorkes SMP di Kabupaten Pati. Journal of Physical Education and Sports, 6(2), 198-204.

Suciati, R., \& Astuti, Y. (2016). Analisis Rencana Pelaksanaan Pembelajaran (Rpp) Mahasiswa Calon Guru Biologi. Edusains, 8(2), 192-200. https://doi.org/10.15408/es.v8i2.4059

Wahyuningsih, W., Jamaluddin, J., \& Karnan, K. (2015). Penerapan Pembelajaran Biologi Berbasis Macromedia Flash Dan Implikasinya Terhadap Keterampilan Metakognitif Dan Penguasaan Konsep Siswa Kelas Viii Smpn 6 Mataram. Jurnal Pijar Mipa, 1O(1). https://doi.org/10.29303/jpm.v10i1.16 